\title{
「インターバル速歩」の新展開 一運動を核にした健康長寿社会の実現をめざしてー
}

\author{
増木 静 江 $^{1,2,3}$, 能 勢 博 ${ }^{3,4}$ \\ (1 信州大学医学系研究科スポーツ医科学, ${ }^{2}$ バイオメデイカル研究所, \\ ${ }^{3} \mathrm{NPO}$ 法人熟年体育大学リサーチセンター, ${ }^{4}$ 信州大学医学系研究科 $\mathrm{e}-$ ヘルスサイエンス $)$
}

私たちの体力は 20 歳台をピークとして, 30歳以降, 10

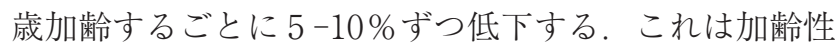
筋肉減弱症（サルコペニア）と呼ばれる加齢現象の一つ である，興味深いのは，この加齢による体力低下と医療 費が見事に相関することである。すなわち，生活習慣病 など，中高年者に特有の疾患はこの加齢性の体力の低下 に起因する可能性が高い. したがって, 運動トレーニン グによって体力を向上させることこそが，これらの加齢 性疾患の予防のための最善の方法と考えられるように なった。

体力向上のための運動処方は，まず，個人の体力（最 高酸素摂取量）を測定し，その $60 \%$ 以上の強度の運動 を 1 日20分以上，週 3 日以上行うのが国際標準である。 しかし, この方法は, ジムなどの体育施設に行き, 専門 スタッフの指導下で自転車エルゴメータなどのマシンを 使って実践する必要がある。この方法は, 時間的, 経済 的に恵まれている人たちには受け入れられても一般庶民 には敷居が高い。このことが体力向上のための運動処方 の全国民への普及を妨げていた。

そこで，私たちは，中高年者を対象に，ジムに設置さ れているマシンを使わなくても体力向上が可能な運動卜 レーニング方法である「インターバル速歩」を考案し, さらに，遠隔で運動指導が受けられる「IoTによる個別 運動処方システム」を開発し，過去16年にわたり，9,600 名を対象に 5 ケ月間のインターバル速歩の体力向上・生 活習慣病改善効果を実証してきた ${ }^{1)}$ 。このトレーニング システムには 3 つの特徵がある.すなわち，1）インター バル速歩：個人の最高酸素摂取量の $70 \%$ 以上に相当す る速歩と約 $40 \%$ の普通歩行をそれぞれ 3 分間ずつ, 計 30分/日以上，4 日/週以上行うトレーニング方法，2） 携帯型カロリー計： 3 軸加速度計と気圧計を内蔵し傾斜 地でも速歩時のエネルギー消費量を正確に測定できる装 置, 3 ) IoTによる個別運動処方システム: 携帯型カロリー 計に記録された歩行データを PC端末からインターネッ トを介してサーバーに送信すると，折り返しコメントが 送り返されてくるシステム，である。同トレーニングの 5 ケ月間の継続率は $95 \%$ と非常に高く, これに比例して, 体力が $15 \%$ 向上，高血圧など生活習慣病の症状が $20 \%$ 改善, うつ症状と膝関節痛の症状がそれぞれ 50 \% 改善, 医療費が20\%抑制されることを明らかにした ${ }^{11}$.
次に, これらのインターバル速歩の効果についてト レーニングの強度と量に注目した検証を行った ${ }^{22}$ 。対象 者679名（平均年齢65歳）において，5 ケ月間のトレー ニング中，指導通り速歩と普通歩行を半々やった者，ほ とんど普通歩行をせずに速歩ばかりやった者，そして， その逆の者もいた。そこで, 彼らの 5 ケ月間のトレーニ ング量を，それぞれ 1 週間当たりの速歩時間，普通歩行 時間, 総歩行時間に基づいて小グループに分け, 体力向 上，生活習慣病改善効果に対してプロットした。その結 果, 体力向上, 生活習慣病改善効果は 1 週間当たりの速 歩時間「のみ」に比例し, 普通歩行時間や総歩行時間に は比例しなかった，すなわち，中高年者の体力向上・生 活習慣病改善のためには本人がややきついと感じる速歩 を実施した時間が重要で, 楽な歩行を漫然と長時間実施 してもあまり効果がないことが明らかとなった ${ }^{2)}$.

一方，同システムでは，参加者が公民館などの地域拠 点から, 専用カロリー計内の歩行記録をサーバーに転送 し，運動指導を受ける必要があり，それはリタイア世代 に可能でも, 現役世代には不便であった。 そこで, 最近, 日本医療研究開発機構 (AMED) の助成により, 同システ ムの汎用性を高めるスマホアプリの開発を行った。すな わち, 従来のカロリー計機能をスマホに搭載し速歩時の エネルギー消費量を正確に測定できるようにし，さらに 高い定着率を担保するため,「自己比較」,「他者比較」,「仲 間づくり」を促すプログラムを搭載した，その現場検証を， 自治体 (60名, 平均年齢67歳), 病院 (56名, 65歳), 企業 (60 名, 38 歳), 大学 (57名, 22歳) の各モデルで行い, 開発し たシステムと従来のシステム間で 5 ケ月間のインターバ ル速歩の定着率と効果に差がないことを確認した ${ }^{1)}$.この アプリを活用しインターバル速歩効果に関する数万人規 模のデータベースの構築を目指す. 将来, このデータベー スとトレーニング中の運動強度の“紐づけ”を行い，その 効果を予測し個人に逐次フィードバックすることで, 運 動の定着を促進することが可能になる。それは，運動を 核にした健康長寿社会の実現に寄与すると考えている。

1) Masuki S, Morikawa M, Nose H. Compr Physiol 10: 1207-1240, 2020.

2) Masuki S, Morikawa M, Nose H. Mayo Clin Proc 94: 2415-2426, 2019. 